\title{
(j)
}

AL-DZIKRA

Jurnal Studi Ilmu Al-Qur'an Dan Al-Hadits http://ejournal.radenintan.ac.id/index.php/al-dzikra

Volume 13, No. 2, Desember Tahun 2019, Halaman 113 - 136

DOI://dx.doi.org/10.24042/al-dzikra.v13i2.3640

\section{KONTROVERSI SURAT AL-FATIHAH DALAM PANDANGAN ARTHUR JEFFERY}

\author{
Muhammad Luthfi Dhulkifli \\ UIN Sunan Kalijaga Yogyakarta \\ luthfidhulkifli@gmail.com
}

\section{Abstract}

Amongst some orientalist of Qur'anic studies, Arthur Jeffery was one of the controversial figures for the idea of a critical edition of the Qur'an. For Jeffery, the Qur'an existed today is unreasonable and its arrangement is clearly haphazard. One of his critical argument is surah al-Fatihah which indicated not originally part of the Qur'an. His work "the variant readings of the Fatihah" showed some peculiar nature of al-Fatiha with the evidence of two Fatihah different versions. Jeffery's variants study is a polemical argument as its contradicts to the Muslim scholar arguments. For Muslim scholars, al-Fatihah is an integrated part of Qur'an. Therefore, this article will analyze Jeffery's argument on al-Fatihah through a descriptive-analytic method. Based on historical, language, and qira'ah study, Jeffery's argument is incorrect. In addition, Jeffery failed to show the existence of his evidence of variant of al-Fatihah.

Keywords: Critic; Controversy; Fatiha; Muslim; the Qur'an 


\section{Abstrak}

Diantara sekian banyak para orientalis pengkaji al-Qur'an, Arthur Jeffery merupakan salah satu sosok yang paling kontroversial dengan gagasannya untuk membuat al-Qur'an edisi kritis. Menurut Jeffery, al-Qur'an yang ada saat ini sangat tidak jelas dan susunannya dilakukan secara sembarangan. Salah satu bagian yang Jeffery kritisi adalah surat al-Fatihah yang dianggap bukan bagian dari al-Qur'an. Dalam tulisannya yang berjudul the variant readings of the Fatihah, dia menunjukkan kejanggalan dalam surat al-Fatihah dengan menunjukkan bukti dua variasi surat al-Fatihah yang berbeda. Kajian ini mengundang polemik karena bertentangan dengan pandangan para sarjana Muslim yang menganggap al-Fatihah sebagai bagian penting dari al-Qur'an. Tulisan ini akan menganalisasi pandangan Jeffery terhadap surat al-Fatihah melalui metode deskriptif-analitis. Melalui kajian historis, kebahasaan, dan ilmu qira'at, argumen skeptis Jeffery terhadap al-Fatihah terbantahkan. Ditambah lagi, Jeffery tidak mampu membuktikan keberadaan variasi surat al-Fatihah yang dia yakini.

Kata Kunci: al-Fatihah; al-Qur'an; Kontroversi; Kritik; Muslim.

\section{A. Pendahuluan}

Tidak hanya oleh kaum Muslim, al-Qur'an banyak mendapatkan respon dan kajian dari kalangan orientalis. Kajian para orientalis diantaranya fokus pada kesejarahan teks, varian bacaan, dan relasi al-Qur'an dengan kitab-kitab suci sebelumnya. ${ }^{1}$ Kajian-kajian tersebut muncul dalam beragam motif, mulai dari agama, kolonialisme, politik, hingga murni keilmuan. ${ }^{2}$ Pada masa ini, banyak orientalis yang mengadopsi penggunaan studi historis kritis dalam mengkaji al-Qur'an. ${ }^{3}$ Kajian ini menimbulkan

1 Abdul Mustaqim, Metode Penelitian Al-Qur'an dan Tafsir, (Yogyakarta: Idea Press Yogyakarta, 2014), hlm. 105

${ }^{2}$ Hasan Abdul Rauf dan Abdurrahman Ghirah, Orientalisme dan Missionarisme: Menelikung Pola Pikir Umat Islam, (Bandung: Remaja Rosdakarya, 2007), hlm. 15

Abdullah Saeed, The Qur'an: an Introduction, (New York: Routledge, 2008), hlm. 106 
polemik bagi para sarjana Muslim awal karena mereka mengabaikan pandangan Islam tentang asal-usul al-Qur'an.

Kajian para orientalis tersebut kemudian direspon secara beragam oleh kalangan Muslim, baik secara positif maupun negatif. Dalam perkembangannya, kajian yang dilakukan para orientalis terus muncul seiring dengan kajian yang berusaha membantahnya. Para orientalis banyak yang mempertanyakan pemahaman tradisional Muslim tentang asal usul kitab melalui kajian yang mereka terapkan. ${ }^{4}$ Salah satu orientalis terkemuka pengkaji al-Qur'an adalah Arthur Jeffery yang memiliki gagasan ambisius untuk membuat al-Qur'an edisi kritis (Critical edition of Qur'an). Usaha Jeffery membuat al-Qur'an edisi kritis bermula pada 1926 ketika dia berkolaborasi dengan Gotthelf Bergstraesser dan Otto Pretzl. Jeffery menggunakan pendekatan kajian kritis historis dalam usahanya merekonstruksi ulang al-Qur'an.

Dalam kajian kritis historisnya, Jeffery juga memandang surat al-Fatihah bukan merupakan bagian dari al-Qur'an. Jeffery menemukan adanya kejanggalan dari bentuk redaksi surat alFatihah. Secara redaksional, pola al-Qur'an secara keseluruhan menunjukkan bahwa Allah bertindak sebagai penyeru dan perintah terhadap umat manusia. Akan tetapi, surat al-Fatihah menunjukkan hal yang sebaliknya dimana manusia yang bertindak sebagai penyeru. Jeffery lantas menyatakan bahwa al-Fatihah adalah surat yang dimasukkan belakangan oleh para pengkodifikasi al-Qur' an pada masa itu. ${ }^{5}$ Al-Fatihah bukan bagian asli dari al-Qur'an, namun sengaja diletakkan di awal karena bentuknya yang tidak biasa dan tidak dikenal di kebiasaan Arab dulu. Kesimpulan Jeffery ini menimbulkan polemik bagi umat Muslim karena al-Fatihah merupakan surat yang selalu dibaca dalam setiap raka'at salat lima waktu. ${ }^{6}$ Selain itu, al-Fatihah merupakan surat yang paling banyak dihafal seluruh Muslim di dunia.

${ }^{4}$ Hamid Fahmy Zarkasyi, Tradisi Orientalis dan Framework Studi AlQur'an, Jurnal Tsaqafah, 2011, hlm. 22

5 Arthur Jeffery, "A Variant Text of the Fatiha", dalam The Muslim World, Vol 29, 1939, hlm. 158

${ }^{6}$ Abdullah Saeed, The Qur'an: an Introduction, hlm. 39 
Keberanian Jeffery mempertanyakan keberadaan surat alFatihah menjadi satu hal kontroversial karena surat tersebut sudah dianggap mapan dalam susunan al-Qur'an. Terkait surat alFatihah, perdebatan umat Muslim sejauh ini berkisar pada lafal basmallah di dalamnya, bukan mengenai apakah itu bagian dari alQur'an atau tidak. Anggapan yang dikemukakan Jeffery sangat bertolak belakang dengan kenyataan yang ada saat ini bahwa surat al-Qur'an berjumlah 114 dimulai al-Fatihah dan diakhiri surat al-Nās. Di sisi lain, pernyataan Jeffery ini memunculkan anggapan bahwa kritiknya terhadap al-Qur'an hanya upaya untuk melemahkan dan menimbulkan keraguan bagi umat Muslim.

\section{B. Biografi Singkat Arthur Jeffery}

Arthur Jeffery merupakan seorang penganut protestan yang lahir di Melbourne 18 Oktober 1892. Dia dikenal sebagai ahli sejarah Timur Tengah dan professor bahasa Semit di School of Oriental Studies di Kairo. Jeffery menyelesaikan pendidikan sarjana pada tahun 1918 lalu dua tahun kemudian menyelesaikan magister di University of Melbourne. Setelah menyelesaikan pendidikannya, dia pergi ke Madras dan mengajar di Akademi Kristen Madras. Disini, dia bertemu dengan Pendeta Edward Sell (1839-1932), seorang dosen sekaligus missionaris yang jauh lebih senior. Pendeta Edward Sell merupakan sosok yang paling memacu Jeffery untuk mengkaji historisitas al-Qur' an. ${ }^{7}$ Meskipun demikian, Jeffery berpendapat bahwa gagasan Sell tidaklah orisinil karena hanya berupa ringkasan dan penyederhanaan dari karya Theodor Noldeke (1836-1930), Geschichte de Qorans atau Sejarah al-Qur'an.

Setelah selesai mengajar di Madras, Jeffery mendapat tawaran dari Dr. Charles R. Watson untuk menjabat sebagai staf di Fakultas School of Oriental Studies pada tahun 1921 di Kairo. Tempat ini merupakan pusat berkumpulnya para misionaris internasional seperti Earl E. Elder, William Henry Temple Graidner, dan Samuel Marinus Zwemer, yang merupakan pendiri Konferensi Umum Misionaris Kristen sekaligus pendiri jurnal The

7 Arthur Jeffery, "The Quest of The Historical Mohammed" dalam The Muslim World 16, 1926, hlm. 330 
Muslim World. ${ }^{8}$ Berada bersama para misionaris dan orientalis terkemuka dunia menjadikan pemikiran Jeffery mulai terpengaruh dan sejalan dengan mereka.

Jeffery menikahi Elsie Gordon Walker, sekretaris dari Dr. Charles R. Watson ${ }^{9}$ pada tahun 1923. Enam tahun kemudian, Jeffery mendapat gelar Doktor dari Universitas Edinburgh dengan penghargaan yang sangat istimewa. ${ }^{10}$ Pada tahun 1938, Jeffery mendapat anugerah gelar Doktor dalam kesusastraan (D.Litt) dengan prestasi summa cum laude dari University of Edinburg. Di tahun yang sama, Jeffery meninggalkan Universitas Amerika di Kairo menuju Columbia University di Amerika Serikat. ${ }^{11}$ Jeffery dikenal memiliki beberapa kelebihan diantaranya adalah menguasai sembilan belas bahasa. Karena kelebihan ini, semasa di Columbia University, Jeffery menjabat sebagai Guru Besar di Fakultas Near-Eastern and Middle-East Language sekaligus ketua bidang sejarah agama-agama untuk program doktor.

Pada tahun 1953 sampai 1954, Jeffery menjabat sebagai Direktur Tahunan Pusat Penelitian Amerika (Annual Director of the American Research Centre), Mesir. Ketika menjabat posisi tersebut, Jeffery mengedit Muqaddimatāni fì Ulümi al-Qur'an wa humā Muqoddimah Kitab al-Mabāni wa Muqoddimah Ibnu Atiyyah (Dua Muqaddimah Ulumul Qur'an: Muqaddimah Kitab al-Mabāni dan Muqaddimah Ibnu Atiyyah) yang diterbitkan di Kairo pada tahun 1954. Jeffery terus mengkaji al-Qur'an secara

${ }^{8}$ Adnin Armas, “Arthur Jeffery: Orientalis Penyusun al-Qur'an Edisi Kritis”, dalam Majalah Islamia, Vol. III No.1, 2006, hlm. 75

9 Dr. Charles R. Watson merupakan seorang presiden pertama dari American University Cairo. Sebagai presiden pendiri, pengabdiannya sebagai presiden dari tahun 1919 sampai 1945 sangat membentuk cara di mana AUC berevolusi. Misalnya, fakta bahwa AUC pada awalnya terkait dengan beberapa masalah sepanjang sejarah AUC. Misalnya, selama kampanye anti-misionaris tahun 1930-an, orang Mesir melancarkan protes terhadap orang-orang Protestan yang mereka percaya untuk mencoba mengubahnya. Watson mampu mengatasi hambatan ini dengan mengadopsi nada yang lebih mendamaikan dan mengkompromikan. Selain itu, Watson memimpin AUC ke arah yang kurang menekankan agama.

${ }^{10}$ Arthur Jeffery, "Christian at Mecca" dalam The Muslim World 19, 1929, hlm. 235

${ }^{11}$ Gabriel Said Reynolds (ed), The Qur'an in Its Historical Context, (London: Routledge, 2008), hlm. 3 
konsisten sampai akhir hidupnya melalui beberapa gagasannya terkait al-Qur'an. Gagasan-gagasan Jeffery banyak dituangkan dalam Jurnal The Muslim World dan tulisan pertamanya adalah "Eclecticism in Islam".

Pada tahun 1957, Jeffery menerbitkan buku berjudul The Koran, Selected Suras: Translated from the Arabic. Dalam buku ini, Jeffery menerjemahkan 64 surat al-Qur'an dan memberikannya catatan-catatan. Jeffery menyusun sendiri urutan surat-surat yang menggambarkan keyakinannya tentang susunan surat dalam al-Qur'an yang sebenarnya. Jeffery tidak menganggap al-Fatihah sebagai bagian dari al-Qur'an. Bagi Jeffery, surat kedua bukan al-Baqarah, tetapi al-Alaq, surah ketiga bukan Ali-Imran, tetapi al-Mudașir. ${ }^{12}$ Sebelumnya, susunan surat yang mirip karya ini sudah dilakukan oleh para orientalis lain seperti Theodore Noldeke, Friederich Schwally, Edward Sell, Richard Bell dan Regis Blachere. Jeffery meninggal dunia pada tanggal 2 Agustus 1959 di South Milford, Kanada dan dimakamkan di Perkuburan Woodlawn, pinggiran Annapolis Royal di Lequille, Kanada. Kepergiannya meninggalkan perasaan duka yang sangat mendalam bagi kawan-kawan dan muridmuridnya. Pada awal Januari tahun 1960, jurnal The Muslim World memuat tulisan ringkas dari para sahabatnya yang memuji kepribadian dan intelektualnya.

\section{Kritik Arthur Jeffery Terhadap al-Qur'an}

Arthur Jeffery memulai kajian kritik historis al-Qur'an sejak tahun 1926 dengan mengumpulkan data yang bisa didapatkan dari berbagai sumber seperti buku-buku tafsir, hadis, kamus, qira'ah, karya-karya filologis dan manuskrip-manuskrip al-Qur'an. ${ }^{13}$ Semua ini dilakukan untuk merealisasikan gagasan yang sangat ambisius yaitu membuat al-Qur'an edisi kritis (a critical edition of the Qur'an). Jeffery membuat edisi kritis alQur'an bersama dua koleganya di Munich, Proffesor Bergstrasser

${ }^{12}$ Adnin Armas, “Arthur Jeffery: Orientalis Penyusun al-Qur'an Edisi Kritis", hlm. 76

13 Arthur Jeffery, "Islam: Muhammad and His Religion", dalam The Muslim World, 1958, hlm. 47-48. Lihat juga Taufik Adnan Amal, Rekonstruksi Sejarah Al-Qur'an, (Jakarta: Yayasan Abad Demokrasi, 2011), hlm. 435 
dan Otto Prezl karena melihat kondisi al-Qur'an yang rentan dengan kesalahan dan pemalsuan. ${ }^{14}$ Jeffery bertugas sebagai pengumpul variasi manuskrip dari sumber-sumber literatur Islam. Sementara kedua koleganya melakukan dokumentasi terhadap manuskrip yang berhasil ditemukan. ${ }^{15}$ Menurut Jeffery, gagasan ambisius ini bisa direalisasikan melalui dua hal, pertama, menampilkan hadis-hadis mengenai teks al-Qur'an. Kedua, menghimpun dan menyusun segala informasi yang tersebar di dalam seluruh kesusasteraan Arab, yang berkaitan dengan varian bacaan (varratio lection) yang resmi dan tidak resmi tentang kritik historis al-Qur'an.

Jeffery berharap dapat membuat terobosan baru dalam studi sejarah teks al-Qur'an. Usaha keras Jeffery bersama koleganya dalam menghimpun segala informasi mengenai alQur'an gagal dikarenakan dua koleganya meninggal pada Perang Dunia II. Ditambah lagi, segala bahan yang telah mereka kumpulkan di Munich musnah terkena bom tentara sekutu. ${ }^{16}$ Diperkirakan, sekitar 40.000 naskah mereka harus hilang karena peristiwa ini. Jeffery mengatakan:

"so that the whole of that gigantic task has to be started over again from the beginning. It thus extremely doubtful if our generation will see the completion of really critical edition of the Qur'an"17

"Maka seluruh tugas kolosal harus dimulai lagi dari awal. Jadi, amat sangat diragukan jika generasi kita akan melihat kesempurnaan teks al-Qur'an edisi kritis yang sebenarnya."

Melalui proyek al-Qur'an edisi kritisnya, Jeffery berusaha meletakkan kembali surat-surat al-Qur'an dalam sistematika tertentu karena al-Qur'an yang ada saat ini tersusun secara

${ }^{14}$ Muhammad Musthofa Al-A'zami, The History of the Qur'anic Text From Revelation to Compilation: A Comparative Study With the Old and New Testamentt, (Al-Qalam Publishing, 2011), hlm. 304

${ }^{15}$ Keith E. Small, Textual Criticism and Qur'an Manuscripts, (UK: Rowman \& Littlefield Publisher,inc, 2011), hlm. 31

${ }^{16}$ Gabriel Said Reynolds (ed), The Qur'an in Its Historical Context, hlm. 5

17 Arthur Jeffery, The Qur'an as scripture, (New York: R. F. Moore Co. 1952), hlm. 103 
sembarangan. ${ }^{18}$ Salah satu alasan terbesar Jeffery membuat edisi kritis al-Qur'an adalah bahwa al-Qur'an yang ada saat ini tidak kritis dan belum memuaskan karena tidak memuat pengaruh bahasa asing. Dalam pandangan Jeffery, al-Qur'an telah terpengaruh berbagai bahasa asing seperti Ethiopia, Aramaik, Ibrani, Syria, Yunani kuno, Persia, dan lainnya. Jadi, kosa kata yang ada di dalam al-Qur'an mengambil istilah-istilah dari Yahudi, Kristen dan budaya lain. ${ }^{19}$ Jeffery membuktikan pernyataannya mengenai pengaruh kosa kata asing ini melalui karyanya yang diterbitkan tahun 1938 dengan judul The Foreign Vocabulary of the Qur'an.

Di dalam karya tersebut, Jeffery membahas sekitar 316 kata di dalam al-Qur'an yang dia anggap berasal dari kosa kata asing. Apabila pengaruh kosa kata asing di dalam al-Qur'an mampu dieksplorasi dengan baik, Jeffery berharap akan ada kamus al-Qur'an yang memuat sumber-sumber filologis, epigrafi, dan analisa teks. Kamus tersebut bisa dibandingkan dengan kamus yang sudah digunakan untuk Perjanjian Lama dan Perjanjian Baru. Kamus ini juga akan berguna untuk meneliti secara menyeluruh kosa kata al-Qur'an.

Melalui pendekatan filologis terhadap al-Qur'an, Jeffery ingin menyimpulkan bahwa kosa kata dan isi ajaran al-Qur'an diambil dari tradisi kitab suci Yahudi, Kristen, dan budaya lain. Dengan demikian, Nabi Muhammad telah meminjam, mengubah, dan menggunakan istilah-istilah asing tersebut untuk disesuaikan dengan kepentingannya. ${ }^{20}$ Adanya kesamaan antara kitab satu dengan kitab-kitab sebelumnya merupakan sebuah kewajaran dan akan sangat mudah ditemukan. ${ }^{21}$ Persamaan kosa kata al-Qur'an dengan bahasa lain tidak bisa diartikan secara mutlak bahwa alQur'an terpengaruh dengan bahasa-bahasa lain. Islam membawa makna baru karena justru mengkritik ajaran Yahudi dan Kristen

${ }^{18}$ Arthur Jeffery, Islam: Muhammad and His Religion, (New York: The Liberal Art Press. Inc, 1958), hlm. 47

${ }^{19}$ Al-Makin, Antara Barat dan Timur: Batasan, Dominasi, Relasi, dan Globalisasi, (Yogyakarta: Suka Press, 2017), hlm. 108

${ }^{20}$ Arthur Jeffery, Islam: Muhammad and His Religion, hlm. 47

${ }^{21}$ Hamid Fahdy Zarkasyi, "Tradisi Orientalis dan Framework Studi Al-Qur'an”, hlm. 14 
yang telah terdistrosi. ${ }^{22}$ Islam menyempurnakan kekurangan dan kesalahan yang ada di dalam agama tersebut. Jadi, sejumlah kosa kata asing beserta ajaran mengenai agama Yahudi dan Kristen telah diislamkan atau diisi dengan makna dan ajaran baru dari Islam.

Mengenai kesejarahan al-Qur'an, Jeffery meyakini bahwa pada awalnya al-Qur'an tidak memiliki titik, tidak memiliki huruf vokal, dan ditulis dengan bentuk huruf kufi. Kenyataan ini sangat berbeda dengan apa yang ditemukan di masa kini. Al-Qur'an saat ini sudah ditandai dengan huruf vokal, ditandai dengan titik, serta berbagai bentuk tulisan. Jeffery menyatakan bahwa pengubahan terhadap teks tersebut adalah kesengajaan yang disertai dengan niat pemalsuan. ${ }^{23}$ Sikap skeptisme Jeffery merupakan sebuah kewajaran jika dilihat dari kecenderungan para orientalis dalam melihat al-Qur'an. Sebaliknya, bagi umat Islam, klaim tersebut dinilai terlalu berlebihan yang dibangun dengan alasan yang mengada-ada. Alasan ini bertolak belakang dengan tradisi kebudayaan orang Arab yang memiliki hafalan kuat. Beberapa riwayat menambahkan bahwa budaya menghafal bangsa Arab juga diiringi dengan budaya tulis di antara beberapa sahabat yang mampu membaca dan menulis. ${ }^{24}$ Dari riwayat ini, dapat dikatakan bahwa penjagaan al-Qur'an sebenarnya telah dilakukan dengan budaya hafalan dan tulisan.

Jeffery mengkritisi keyakinan para Muslim berdasarkan riwayat tersebut karena dianggap sebagai alasan ortodok. Dia juga mengkritisi sejarah pewahyuan yang menyatakan bahwa kedatangan Malaikat Jibril untuk melakukan muraja'ah pada Nabi adalah alasan ortodok. ${ }^{25}$ Menurut Jeffery, hal yang harus diperhatikan adalah proses kodifikasi al Qur'an belum ada pada masa Nabi dan baru dilakukan di masa khalifah Usman. Dari sini, Jeffery kemudian berpendapat bahwa ada kemungkinan manuskrip di zaman Nabi ada yang tidak terkumpulkan atau hilang. Dalam

${ }^{22}$ Adnin Armas, "Kritik Arthur Jeffery Terhadap al-Qur'an”, hlm. 10

${ }^{23}$ Arthur Jeffery, "The Textual History of Qur'an" dalam The Qur'an as scripture, (New York: R. F. Moore Co, 1952)

24 Manna al-Qaththan, Mabahits fi 'Ulum al-Qur'an (Riyadh: Mansyurat al-'Ashr al-Hadits, 1990), hlm. 118-119

${ }^{25}$ Arthur Jeffery, Islam: Muhammad and His Religion, hlm. 48 
keyakinannya, semua pembuktian terkait penjagaan al-Qur'an harus terdapat bukti valid yang bisa diteliti. Argumen Jeffery kontradiktif dengan catatan sejarah bahwa masyarakat Arab pada masa tersebut adalah masyarakat dengan tradisi lisan dan belum banyak yang mampu menulis dengan baik. Sejarah penulisan dan pengumpulan al-Qur'an baru dimulai serius pada masa khalifah Usman sehingga akan sulit menemukan manuskrip pada masa Nabi.

Pendapat Jeffery berikutnya adalah banyaknya para qurra' yang mengumpulkan qira'ah dalam beragam mushaf, seperti Salim Ibn Mu'qib, 'Ali bin Abi Thalib, Anas bin Malik, Abu Musa al-Asy'ari, Ubay bin Ka'ab, 'Abdullah bin Mas'ud, dan beragam mushaf yang sudah beredar di berbagai wilayah, seperti mushaf Miqdad bin al-Aswad yang berdasarkan kepada mushaf Ibn Mas'ud beredar di Damaskus. Mushaf Ibn Mas'ud ini banyak digunakan di daerah Kufah. Mushaf Abu Musa al-Asy'ari di Basra dan mushaf Ubay bin Ka'ab di Syria. ${ }^{26}$ Mushaf-mushaf tersebut berbeda dengan mushaf Usmani. Dengan demikian, ketika mushaf Usmani dijadikan satu teks standar yang resmi dan digunakan di seluruh wilayah kekuasaan Islam, maka kanosisasi tersebut tidak terlepas dari alasan-alasan politis. ${ }^{27}$ Alasan politis seperti asumsi Jeffery tidak bisa disalahkan sepenuhnya karena ada pertimbangan kebaikan umat (al-mașlahah).

Beberapa laporan menyebutkan ada empat naskah alQur'an saat itu: Kufah, Basra, dan Suriah, yang satu lagi disimpan di Madinah. Riwayat lain menambahkan Makkah, Yaman dan Bahrain. Professor Shauqi Daif meyakini bahwa delapan naskah telah dibuat karena Usman mengambil satu untuk diri sendiri. ${ }^{28}$ Untuk menguatkan pendapat ini, Khalid bin Ilyas telah membuat perbandingan antara mushaf yang disimpan Usman dan yang disediakan untuk Madinah, oleh karena itu, delapan tempat untuk

${ }^{26}$ Farhat Aziz, "Western Scholars and Variant Readings of the Holy Qur'ān (An Analysis the objections of Arthur Jeffery and A.T. Welch)" dalam British Journal of Humanities and Social Sciences 1 March 2012, Vol. 4, hlm. 40

${ }^{27}$ Arthur Jeffery, Material for the History of the Text of the Koran: The Old Codices, (Leiden: E. J. Brill, 1937), hlm. 8

${ }^{28}$ Muhammad Musthofa Al-A'zami, The History of the Qur'anic Text From Revelation to Compilation, hlm. 94 
naskah mushaf kelihatannya lebih masuk akal. Al-Ya'qubi, seorang sejarawan Syi'ah berkata bahwa Usman mengirim mushaf ke Kufah, Basra, Madinah, Mekah, Mesir, Suriah, Bahrain, Yaman, dan al-Jazirah, jumlah keseluruhannya adalah sembilan. Dari semua mushaf yang ada tersebut, memang terdapat beberapa perbedaan sederhana dan tidak terlalu signifikan. Seluruh mushaf ini kemudian dikenal dengan sebutan mushaf imam. ${ }^{29}$ Hal ini menjadi bukti bahwa selama proses penyiapan naskah mushaf tersebut, beberapa orang menulis sejumlah naskah lain untuk kegunaan mereka masing-masing dan tidak ada konflik pertentangan diantara mereka. Tindakan khalifah Usman melakukan standarisasi lebih tepat dimaknai sebagai langkah untuk menghindari berbagai kesalahan yang mungkin terjadi di dalam mushaf-mushaf pada al-Qur'an. Di samping politis, tindakan yang diambil Usman dilatarbelakangi niat untuk mempertahankan kebenaran otentitas al-Qur'an.

\section{Surat al-Fatihah Versi Arthur Jeffery}

Diantara diskursus yang menjadi pembahasan Arthur Jeffery adalah kritiknya terhadap surat al-Fatihah. Jeffery menyatakan:

"Sura I of the Koran bears on its face evidence that it was not originally part of the text, but was a prayer composed to be placed at the head of the assembled volume, to be recited before reading the book, a custom not unfamiliar to us from otheer sacred books of the Near east. The koranic style, as is well known, is that it from the beginning to end, Allah is addressing man. In the Fatiha, however, it is man addressing Allah,..."30

Jeffery membuktikan bahwa keraguan terhadap al-Fatihah tidak hanya datang dari sarjana Barat lain seperti Theodor Noldeke, namun juga dari para sarjana Muslim, seperti Fakhr alDin al-Razi yang mengutip pendapat Abu Bakr al-Asamm. AlAsamm memulai pembahasannya dari surat al-Baqarah karena meyakini al-Fatihah bukan bagian dari al-Qur'an yang

29 Abdul Syabur Syahin, Saat Al-Qur'an Butuh Pembelaan: Sebuah Analisis Sejarah, (Jakarta: Penerbit Erlangga, 2006), hlm. 219

${ }^{30}$ Arthur Jeffery, “A Variant Text of the Fatiha”, hlm. 159 
dilandaskan pada mushaf Ibn Mas'ud yang tidak memasukkan alFatihah di dalamnya. Al-Asamm juga mengatakan bahwa alFatihah tidak ditemukan dalam naskah kufi al-Qur'an awal. Kalaupun ada, maka akan ditulis di akhir naskah tersebut. Jeffery menambahkan bahwa adanya keberagaman atas bacaan dan tulisan al-Fatihah disebabkan karena bukan bagian dari al-Qur'an.

Pada dasarnya, al-Razi bukan ingin mengatakan bahwa alFatihah bukan bagian dari al-Qur'an. Hal ini terlihat pada awal muqaddimah tafsir karya al-Razi. Al-Razi menyebut bahwa alFatihah tidak satu kesatuan dengan surat-surat lainnya, namun keterpisahan ini bukan disebabkan atas keyakinan al-Razi bahwa al-Fatihah bukan bagian dari al-Qur'an. Menurut al-Razi alFatihah merupakan surat yang terlalu rumit untuk dibahas, sehingga butuh pembahasan khusus dan mendalam. Al-Razi menjelaskan tafsir surat al-Fatihah secara luas dengan lebih dari 60 halaman yang belum termasuk pembahasan mengenai basmallah di dalamnya. ${ }^{31}$ Al-Razi juga memberikan banyak pandangan tentang al-Fatihah dalam muqaddimahnya secara khusus. Dengan demikian, keberadaan al-Fatihah sebagai bagian dari al-Qur'an diakui oleh al-Razi, bukan seperi yang diasumsikan oleh Jeffery.

Untuk membuktikan asumsinya secara lebih mendalam mengenai kedudukan al-Fatihah, Jeffery mengutip bacaan yang beredar di kalangan Syi'ah seperti tertulis dalam kitab Tadzkirah al-A'imma yang ditulis oleh Muhammad Baqir Majlisi (Teheran, 1331, halaman 18):

\begin{tabular}{|c|c|}
\hline $\begin{array}{l}\text { Kita memuji Allah, Tuhan } \\
\text { seluruh alam }\end{array}$ & تُعَحَبِدُ اللَهَ رَبَّ الْعَالَمْنِنَ \\
\hline $\begin{array}{l}\text { Yang Maha Pengasih lagi Maha } \\
\text { Penyayang }\end{array}$ & آلرَََحْمَنَ الرَََحِيْمَ \\
\hline $\begin{array}{l}\text { Dia yang memiliki Hari } \\
\text { Pembalasan }\end{array}$ & مَتَلَكَ يَوْمِ الدِّيْنِ \\
\hline $\begin{array}{l}\text { Hanya kepada Engkau kami } \\
\text { menyembah, dan hanya kepada } \\
\text { Engkaulah kami memohon }\end{array}$ & 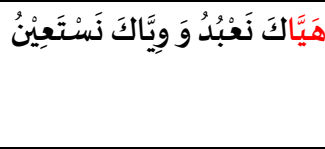 \\
\hline
\end{tabular}

${ }^{31}$ Fakhr al-Din al-Razi, Tafsir al-Kabir auw Mafatih al-Gaib. Juz I. (Beirut: Dar al-Fikr), hlm. 223 


\begin{tabular}{|l|c|}
\hline pertolongan & \\
\hline Engkau yang menunjukkan jalan & \\
yang lurus & \\
\hline jalan orang-orang yang telah & \\
Engkau tunjukkan nikmat kepada & \\
mereka & \\
\hline $\begin{array}{l}\text { Bukan ( jalan) mereka yang } \\
\text { dimurkai, dan bukan (pula jalan) }\end{array}$ & \\
mereka yang sesat & \\
\hline
\end{tabular}

Tabel 1. Variasi surat al-Fatihah pertama (bagian berwarna merah menunjukkan perbedaan redaksi dengan al-Fatihah yang kita kenal saat ini)

Jeffery menambahkan keterangannya dengan sebuah buku yang dia temukan pada saat kunjungan ke Mesir. Jeffery mendapatkan buku manual fiqih kecil dari seseorang pada saat itu. Buku ini diawali dengan al-Fatihah yang memiliki versi lain. Menurutnya, buku tersebut boleh dicopy dan diperbanyak, asal jangan mencantumkan penulisnya, karena khawatir akan diserang oleh penganut Muslim ortodok. Jeffery pada akhirnya berkilah dengan mengatakan bahwa buku tersebut hilang, hingga belum sempat tahu nama pengarangnya. Jeffery mengutip variasi lainnya dari tulisan Riwayah Abi al- Fath al-Jubba'i 'an Syaikhih al-Susi 'an al-Nahrazwani 'an Abi al- Sa'adah al-Maidani 'an al Marzubani 'an al-Khalil bin Ahmad. ${ }^{32}$ Adapun versi tersebut adalah:

\begin{tabular}{|c|c|}
\hline $\begin{array}{l}\text { Dengan menyebut nama Allah } \\
\text { Yang Maha Pengasih lagi Maha } \\
\text { Penyanyang }\end{array}$ & 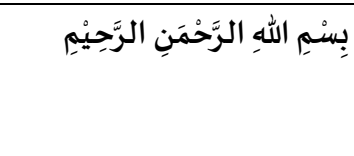 \\
\hline $\begin{array}{l}\text { Segala puji bagi Allah, Penguasa } \\
\text { seluruh alam }\end{array}$ & 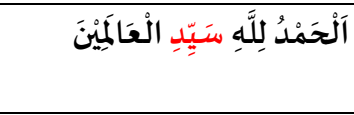 \\
\hline $\begin{array}{l}\text { Yang Maha Melimpahkan Rizki } \\
\text { lagi Maha Penyayang }\end{array}$ & آلَرَََّّاقِ الرَّحِيْيِ \\
\hline $\begin{array}{l}\text { Dia yang memiliki Hari } \\
\text { Pembalasan }\end{array}$ & 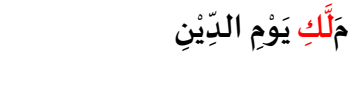 \\
\hline Sesungguhnya hanya kepadaMu & إِنَّ لَكَكَ نَعْبُدُوَوَ إِنَُّ لَكَكَ نَسْنَعِيْنُ \\
\hline
\end{tabular}

${ }^{32}$ Arthur Jeffery, “A Variant Text of the Fatihah”, hlm. 159 


\begin{tabular}{|l|c|}
\hline kami menyembah dan & \\
sesungguhnya kepadaMu kami \\
memohon pertolongan
\end{tabular}

Tabel 2. Variasi surat al-Fatihah kedua (bagian berwarna merah menunjukkan perbedaan redaksi dengan al-Fatihah yang kita kenal saat ini)

Variasi pertama tidak mencantumkan basmallah dalam surat al-Fatihah sedangkan variasi kedua mencantumkannya. Umat Muslim sendiri memiliki beragam pendapat terkait apakah basmallah termasuk bagian dari surat al-Fatihah atau tidak. Contoh nyata perbedaan terkait hal ini adalah pembacaan basmallah dalam surat al-Fatihah ketika sholat yang diucapkan secara jelas dan sebagian membacanya dengan lirih. Basmallah diyakini secara umum sebagai sebuah kalimat yang dilafalkan ketika mulai membaca al-Qur'an. ${ }^{33}$ Jeffery tidak membahas keberadaan basmallah dalam surat al-Fatihah, namun jika dilihat dari kajian qira'ah imam tujuh (qira'ah sab'ah), basmallah selalu diikutkan dalam pembacaan surat al-Fatihah. ${ }^{34}$

Jeffery melakukan analisa kebahasaan terhadap kata-kata yang berbeda dari kedua varian tersebut. Sayyid dan rabb merupakan sinonim kata. Term sayyid digunakan dalam al-Qur'an surat Yusuf ayat 25 untuk Yusuf dan Yahya sebagai raja Mesir pada masa itu. Dari sini, Jeffery meragukan penggunaan kata sayyid karena itu hanya ditujukan bagi para Nabi, namun ternyata dalam al-Fatihah malah digunakan untuk Allah. Sementara, alRazzaq merupakan salah satu nama Allah sebagaimana tersebut

${ }^{33}$ Fakhr al-Din al-Razi, Tafsir al-Kabir auw Mafatih al-Gaib, hlm. 108

${ }^{34}$ Muhammad Arwani Amin, Faidh al-Barakat, (Kudus: Mubarakatan Thayyibah, 2002), hlm. 7 
dalam al-Qur' an surat al-Dariyat: 58. ${ }^{35}$ Dengan argumen tersebut, secara tidak langsung Jeffery meragukan kalimat-kalimat yang tercantum dalam varian al-Fatihah yang dia temukan. Jeffery mengkritisi kalimat sayyid yang kurang sesuai dan tidak membahas $r a b b$ sebagaimana $r a b b$ merupakan kata yang ada dalam surat al-Fatihah saat ini.

Menurut Jeffery, mallak adalah salah satu bacaan imam Kufah di antara tujuh macam qira'at, yaitu bacaan Al-Kisa'i dan bacaan malaka atau malaki adalah bacaan yang sama-sama disetujui. Analisa Jeffery ini bertolak belakang dengan bacaan Imam Kufah di antara tujuh macam qira'at, karena al-Kisa'i tidak membacanya dengan mallak ataupun malaki. Al-Kisa'i membacanya dengan malak. ${ }^{36}$ Jeffery kemudian menyatakan bahwa term malak lebih tepat dibandingkan term alternatif seperti kata mālik atau malik. Bacaan tersebut lebih baik walaupun yang dipakai dalam textus receptus (bacaan yang diterima) adalah jenis bacaan kedua yakni mālik. Jadi, Jeffery mengakui mālik merupakan bacaan yang diterima. Adapun bacaan yang diterima dalam kajian qira'ah tujuh adalah māliki oleh imam 'Ashim dan al-Kisa'i, serta maliki yang dibaca seluruh imam kecuali keduanya. ${ }^{37}$ Adapun bacaan lain yang ditemukan riwayatnya adalah malki dan milk dari riwayat Abi Umar. ${ }^{38}$

Inna laka sejenis dengan hiyyaka, wiyyaka, ayyaka, iyaka dan iyyaka adalah jenis bacaan yang diterima. Term-term ini adalah bentuk usaha untuk menginterpretasikan huruf-huruf konsonan dan huruf-huruf yang tanpa titik, yang terdapat dalam setiap bagian kata sebagaimana terdapat dalam naskah asli. Hiyyaka atau hayyaka adalah bacaan Abu al-Sawwar al-Ghanawi dan Abu al Mutawakkil. Sedangkan wiyyaka atau wayyaka adalah bacaan Abu Raja' ${ }^{39}$ Kalimat-kalimat tersebut jika dilihat dari kajian qira'ah yang mutawatir tidak ditemukan karena semua riwayat mutawatir membacanya dengan iyyaka.

\footnotetext{
${ }^{35}$ Arthur Jeffery. “A Variant Text of the Fatihah”, hlm. 159

${ }^{36}$ Abdul Fatah Qadhi, Al-Budur al-Zahirah fi al-Qira'at al-'Asr alMutawatirah. (Beirut: Dar Kitab al-Ma'arif, 1403 H), hlm. 15

${ }^{37}$ Muhammad Arwani Amin, Faidh al-Barakat, hlm. 8

38 Ibnu Mujahid, Kitab al-Sab'ah fi al-Qira'at, Cetakan II, (Kairo: Dar al-Ma'arif, $324 \mathrm{H}$ ), hlm. 105

39 Arthur Jeffery, “A Variant Text of the Fatihah”, hlm. 160
} 
Arsyidna memiliki kemiripan dengan ihdina yang merupakan bacaan Ibn Mas'ud seperti terdapat dalam naskah yang diterima. Kata perintah semacam ini tidak ditemukan dalam al-Qur'an, namun derivasi kata ini sering digunakan. ${ }^{40}$ Term sabil sebenarnya lebih diterima daripada term sirath. Term ini juga paling sering digunakan dalam al-Qur'an. Menurut Jeffery, kedua term ini adalah diadopsi dari bahasa Aramaik. Adapun kalimat sirath al-mustaqim adalah bentuk iḍafah, dimana al-Mustaqim dianggap sebagai ungkapan untuk Allah. Varian bacaan ini digunakan oleh Ubay, Ja'far Shadiq dan 'Abd Allah bin 'Umar. Bentuk idafah merupakan bacaan yang paling baik dan benar, walaupun kata mustaqīm bukan salah satu dari al-Asmä' al-Husna yang sembilan puluh sembilan. ${ }^{41}$ Jeffery mengakui kalimat sirath al-mustaqim lebih layak digunakan sedangkan kedua varian alFatihah di atas menggunakan redaksi kalimat sabìl al-mustaqīm.

Mananta dan an'amta adalah contoh istilah yang sama dan tidak memiliki perbedaan makna secara signifikan. Bentuk kata na'ama lebih banyak dan lebih sering digunakan dalam al Qur'an dari pada mananta seperti dalam varian al-Fatihah kedua. Selain itu, al Qur'an juga sering menggunakan term manna yang memiliki makna sinonim. Siwā dan gair adalah sinonim, akan tetapi siwā tidak banyak digunakan dalam al-Qur'an. Term gair juga dibaca la oleh 'Umar, Ali, Ibn al-Zubair, Ikrimah, dan alAswad sebagai naskah awal al-Qur' an dan diikuti pula oleh Ja'far Shadiq dan Zaid bin 'Ali. ${ }^{42}$ Jeffery menganggap bacaan lā lebih dapat dipertanggung jawabkan dan lebih punya otoritas untuk dibaca sebagaimana yang ada saat ini.

Beberapa kata dalam surat al-Fatihah disebut Jeffery berasal dari bahasa lain. Kata sirat menurutnya hanya digunakan dalam pengertian religius dan disebut sebanyak lima kali dalam al-Qur'an. Kata ini menurut Jeffery berasal dari bahasa Aram yang diarabkan. ${ }^{43}$ Kata tersebut bisa dibaca dengan mengganti

${ }^{40}$ Arthur Jeffery, “A Variant Text of the Fatihah”, hlm. 160

${ }^{41}$ Arthur Jeffery, “A Variant Text of the Fatihah”, hlm. 161

${ }^{42}$ Arthur Jeffery, "A Variant Text of the Fatihah”, hlm. 162

43 Arthur Jeffery, The Foreign Vocabulary of the Qur'an, Vol III, (Leiden : Brill, 2007), hlm. 196 
huruf sad dengan sin ataupun za, ${ }^{44}$ Fath sebagai kata kerja diartikan penghakiman, keputusan yang berarti untuk membuka. ${ }^{45}$ Meskipun dimuat dalam buku foreign vocabulary, Jeffery menegaskan bahwa kata tersebut merupakan kata asli Arab seperti yang terlihat dari penggunaannya di berbagai prasasti.

Melalui bukunya tersebut, Jeffery menyebut kata mālik adalah malaikat yang bertanggung jawab atas neraka dan merupakan bentuk derivasi dari malak dan berasal dari tradisi Alkitab. ${ }^{46}$ Sementara mālik dalam arti Tuhan maupun kerajaan diadopsi dari bahasa Ibrani, Aramaik, dan Semitik. ${ }^{47}$ Rabb berarti Tuhan, berakar dari bahasa Semit yang sangat umum digunakan bangsa Ibrani dan Aram. Rabb dalam artian Tuhan atau guru dipinjam dari Yahudi atau Kristen yang berasal dari bahasa Aramaik dan telah dikenal bangsa Arab sebelum diturunkannya al-Qur'an. ${ }^{48}$ Argumen Jeffery yang menganggap banyak kata dalam al-Qur'an berasal dari bukan bahasa Arab serupa dengan apa yang dilakukan Christoph Luxenberg, pakar bahasa Semit kuno dengan karyanya Die Syro-Aramäische Lesart des Koran: Ein Beitrag zur Entschlüsselung der Koransprache (2000). ${ }^{49}$ Kajian ini juga telah dikritisi oleh beberapa akademisi seperti Angelika Neuwirth, Hermut Bobzin, dan Stefan Wild.

Terkait surat al-Fatihah, Jeffery menarik kesimpulan bahwa kedua variasi yang dia temukan, termasuk juga al-Fatihah yang ada sekarang adalah sesuatu yang tidak bisa dipertanggung jawabkan. Dalam varian tersebut, ada usaha untuk membangun gramatikal bahasa dengan tujuan memperindahkan dan memperjelas bacaan. Setelah melihat lebih dalam dan jeli, Jeffery menyatakan bahwa al-Fatihah adalah doa yang sering diucapkan

${ }^{44}$ Muhammad Mas'udi Fathurrahman, Metode Praktis Sorogan Qira'at Sab'ah: Teori dan Praktek Ilmu tentang Bacaan Al-Qur'an dan Tata Caranya Menurut Tujuh Imam Ahli Qiro'at. Yogyakarta: Pusat Studi dan Pengembangan Pesantren (PSPP), 2012, hlm. 72

${ }^{45}$ Arthur Jeffery, The Foreign Vocabulary of the Qur'an, hlm. 222

${ }^{46}$ Arthur Jeffery, The Foreign Vocabulary of the Qur'an, hlm. 257

${ }^{47}$ Arthur Jeffery, The Foreign Vocabulary of the Qur'an, hlm. 270

${ }^{48}$ Arthur Jeffery, The Foreign Vocabulary of the Qur'an, hlm. 137

49 Lien Iffah Naf'atu Fina, "Survei Awal Studi Perbandingan AlQur'an dan Bibel dalam Kesarjanaan Barat: Sebuah Perjalanan Menuju Intertekstualitas", Jurnal Suhuf, Vol 8 no 1, 2015, hlm. 135 
oleh Nabi. Hal ini terlihat dari gaya bahasa yang digunakan serta ekspresi yang ada dalam al-Fatihah itu sendiri.

\section{E. Kritik Terhadap Arthur Jeffery}

Jika dilihat secara lebih teliti, Jeffery menekankan bahwa ketika mengkritik teks al-Qur'an rujukannya adalah 'textus receptus' yang dia anggap paling benar. Sejak awal, Jeffery sering sekali menyebut dan berkata bahwa mushaf Usmani yang sekarang sudah tidak lagi murni. Cara berpikir Jeffery semacam ini juga serupa dengan orientalis lain semisal Christoph Luxenberg, Gerd R Puin, dan Claude Gilliot. Hal ini merupakan sebuah kecendurungan yang mirip dengan apa yang dilakukan Abraham Geiger dengan metode filologi klasiknya. ${ }^{50}$ Metode ini selalu mengunggulkan teks yang datang lebih dulu. Metode ini kemudian mengalami banyak kritik di masa kini yang lebih terbuka terhadap kajian intratekstualitas antar sumber.

Jeffery menutup argumen terkait variasi surat al-Fatihah ini dengan menyatakan tidak ada alasan pasti untuk pembacaan varian dari keduanya. Keduanya bukan perubahan untuk kepentingan konstruksi gramatikal yang lebih halus dan tidak memiliki makna doktrinal. Keduanya hanya varian dalam transmisi doa yang pada awalnya dipelihara dalam bentuk lisan lalu kemudian diperbaiki ketika al-Qur'an dibuat. Bentuk varian kedua berasal dari Khalil bin Ahmad, yang dikenal sebagai seorang Pembaca dari Basrah. ${ }^{51}$ Sangat mungkin Khalil memiliki akses terhadap tradisi lama yang baik seperti pembacaan alFatihah yang terdahulu. Selain itu, terdapat beberapa mushaf alQur'an yang tidak sempat dimusnahkan semasa kodifikasi alQur'an. Hal ini sangat memungkinan adanya variasi tersebut karena memang dulunya terdapat ragam dialek al-Qur'an yang berbeda.

Ketika menyatakan al-Fatihah bukan bagian dari alQur'an, Jeffery hanya merujuk pada kitab yang dipegang oleh orang Syi'ah. Dari banyak manuskrip yang ada sebagaimana

50 Lien Iffah Naf'atu Fina, "Survei Awal Studi Perbandingan AlQur'an dan Bibel”, hlm. 138

${ }^{51}$ Chaudary, "Variant Readings of al-Fatihah" dalam The American Journal of Islamic Sosial Science, 12: 2, hlm. 174 
dalam tulisannya, banyak yang lebih menyebut dan mencantumkan surat al-Fatihah. ${ }^{52}$ Sebuah hal yang aneh ketika Jeffery berani meragukan al-Qur'an yang masih eksis hingga saat ini tetapi dia tidak mampu menunjukkan bukti fisik dari argumennya. Alasan bahwa buku yang pernah dia dapat hilang hingga tidak sempat mengetahui nama pengarangnya, dalam hal ini terkesan sebagai hal yang mengada-ada. Bagaimana mungkin seorang orientalis yang selalu berdasar pada bukti valid, mengatakan bahwa buku tersebut hilang tanpa keterangan yang jelas. Jeffery juga mengatakan bahwa buku tersebut adalah buku kecil fiqih. Terasa sangat janggal untuk mengklaim sebuah sumber yang lebih terkenal keotentikannya (al-Qur'an) hanya melalui buku kecil fiqih.

Mengenai perbedaan redaksi yang ada dalam kedua varian al-Fatihah yang tertulis dalam kedua buku yang dimiliki oleh Jeffery, semakin meyakinkan bahwa apa yang ada dalam kedua buku tersebut hanyalah bentuk doa yang ditambahkan oleh penulis buku tersebut, bukan bentuk bacaan al-Fatihah. Hal ini disimpulkan melalui komparasi dengan bacaan-bacaan yang sahih dan diterima, bahwa surat al-Fatihah yang sudah ada sekarang sangat sulit dimungkinkan adanya kesalahan dan kepalsuan karena selalu dilafalkan minimal 17 kali dalam sehari ketika salat sejak masa Nabi Muhammad. Sebagaimana sejarah pembukuan alQur'an yang sangat hati-hati, tidak mungkin hal sepenting surat al-Fatihah begitu mudahnya bagi Usman untuk mencantumkannya dalam al-Qur'an jika memang bukan bagian dari al-Qur'an. Selain itu, ketika Usman membukukan al-Qur'an tidak dilakukan secara sendiri, namun dilakukan oleh beberapa sahabat pilihan ketika itu, seperti Zaid bin Tsabit, 'Abd Allah bin al-Zubair, Sa'id bin al-'Ash, 'Abd al-Rahman bin al-Harits bin Hisyam. ${ }^{53}$ Mereka saling mengkoreksi secara cermat dan berhatihati dalam proses pembukuan al-Qur'an agar dapat meminimalisir adanya kekeliruan. ${ }^{54}$ Dengan proses yang begitu cermat, apabila dimungkinkan terdapat kesalahan, hal tersebut tidak akan sangat

${ }^{52}$ Arthur Jeffery, Materials for The History of the Qur'an, hlm. 16-19

${ }^{53}$ Manna' al-Qaththan, Mabahis fi 'Ulumul Qur'an, hlm. 129

${ }^{54}$ Abdul Syabur Syahin, Saat Al-Qur'an Butuh Pembelaan, hlm. 120- 
fatal seperti banyaknya perbedaan variasi al-Fatihah yang ditunjukkan oleh Jeffery.

Berkaitan dengan proses kodifikasi al-Qur'an, anggapan Jeffery bahwa para pembaca al-Qur'an (qurra') menentang kebijakan standarisasi mushaf Usmani adalah anggapan yang tidak berdasar. Fakta sejarah tersebut menunjukkan adanya kerja sama dari banyak qurra'sebagai bukti bahwa para sahabat saat itu menerima keputusan Usman untuk melakukan standarisasi. Menurut Mus'ab bin Sa'ad, tidak ada seorang pun dari kaum Muhajirin, Anshar, dan orang-orang berilmu mengingkari keputusan Khalifah Usman pada saat itu. Dalam hal ini, para orientalis berpendapat dengan meletakkan akal diatas segalanya. ${ }^{55}$ Para orientalis menolak alasan-alasan yang tidak bisa didiskusikan atau meragukan tanpa adanya bukti historis.

Pada dasarnya, Jeffery bukan orang pertama yang mengkritisi surat al-Fatihah karena lebih dahulu ada sosok Theodor Noldeke yang menganggap al-Fatihah bukan bagian dari pewahyuan dan berasal dari bahasa Yahudi maupun Kristen. ${ }^{56}$ Jeffery maupun Noldeke mungkin tidak menyadari adanya riwayat yang menyatakan bahwa Nabi Muhammad menyebut nama lain al-Fatihah sebagai fătihah al-Kitāb, umm al-Kitāb, umm al-Qur'an, dan lain-lain yang disebutkan dalam al-Qur'an sendiri. ${ }^{57}$ Hal ini menandakan bahwa al-Fatihah memang bagian integral dari al-Qur'an. Selain itu, ada juga riwayat yang menyatakan turunnya al-Fatihah, walaupun masih terdapat perbedaan pendapat, apakah di Makkah atau di Madinah. ${ }^{58}$ Bahkan ada riwayat yang menyatakan surat al-Fatihah turun dua kali, di Makkah dan di Madinah.

55 Qassim Assamurai, Bukti-Bukti Kebohongan Orientalis, (Jakarta : Gema Insani Press, 1996), hlm. 93

56 Theodor Noldeke, The History of the Qur'an, (Leiden: Brill, 2013), hlm. 245

${ }^{57}$ Fakhr Din al-Razi, Tafsir al-Kabir auw Mafatih al-Gaib, hlm. 179

${ }^{58}$ Mahmud al-Alusi, Ruh al Ma'ani fi Tafsir al-Qur'an al-Azim wa Sab’ al-Masani, (Beirut: Turats al-Arabi, 1270 H), hlm. 39 


\section{F. Kesimpulan}

Tidak ada alasan pasti untuk menerima variasi dari surat al-Fatihah ini karena Jeffery tidak mampu menunjukkan bukti yang valid. Dalam tulisannya, Jeffery menyebut bahwa variasi yang ada merupakan transmisi doa yang pada awalnya dipelihara dalam bentuk lisan, dan kemudian diperbaiki ketika al-Qur'an dibuat. Hal ini mengindikasikan bahwa variasi tersebut merupakan sebuah doa yang pernah ada dahulu. Analisa yang diberikan Jeffery merupakan kajian historis yang masih mengundang sejumlah kritik. Di sisi lain, analisis secara kebahasaan dan berdasar pada riwayat qira'ah secara mutawatir, menunjukkan keotentikan surat al-Fatihah yang ada saat ini. Kajian yang dilakukan Jeffery setidaknya telah memberikan realita sejarah yang menarik tentang surat al-Fatihah namun pembuktian yang diberikan Jeffery belum atau tidak bisa membantah kenyataan yang ada bahwa al-Fatihah tetap diyakini sebagai bagian dari surat al-Qur'an. 


\section{DAFTAR PUSTAKA}

A'zami, Muhammad Musthofa, The History of the Qur'anic Text From Revelation to Compilation: A Comparative Study With the Old and New Testament, Al-Qalam Publishing, 2011.

Al-Makin, Antara Barat dan Timur: Batasan, Dominasi, Relasi, dan Globalisasi, Yogyakarta: Suka Press, 2017.

Alusi, Mahmud, Rüh al Ma'āni fì Tafsìr al-Qur'an al-Ażim wa Sab' al-Masāni. Beirut: Turats al-Arabi, $1270 \mathrm{H}$.

Amal, Taufik Adnan, Rekonstruksi Sejarah Al-Qur'an, Jakarta: Yayasan Abad Demokrasi, 2011.

Armas, Adnin, Arthur Jeffery: Orientalis Penyusun al-Qur'an Edisi Kritis, Majalah Islamia, Vol III No.1 2006.

Arwani Amin, Muhammad, Fauḍ al-Barakāt, Kudus: Mubarakatan Thayyibah, 2002.

Assamurai, Qassim, Bukti-Bukti Kebohongan Orientalis, Jakarta: Gema Insani Press, 1996.

Aziz, Farhat, Western Scholars and Variant Readings of the Holy Qur'an (An Analysis the objections of Arthur Jeffery and A.T. Welch), British Journal of Humanities and Social Sciences, 1 March Vol. 4, 2012.

Chaudary, Muhammad \&Variant readings of al-Fatihah, The American Journal of Islamic Sosial Science 12: 2. n,d.

Fathurrohman, Muhammad Mas'udi, Metode Praktis Sorogan Qira'at Sab'ah: Teori dan Praktek Ilmu tentang Bacaan Al-Qur'an dan Tata Caranya Menurut Tujuh Imam Ahli Qiro'at, Yogyakarta: Pusat Studi dan Pengembangan Pesantren (PSPP), 2012.

Fina, Lien Iffah Naf'atu, Survei Awal Studi Perbandingan AlQur'an dan Bibel dalam Kesarjanaan Barat: Sebuah Perjalanan Menuju Intertekstualitas, Suhuf volume 8 no 1, 2015.

Jeffery, Arthur, Material for the History of the Text of the Koran: The Old Codices, Leiden:E. J. Brill, 1937. 

Co, 1952.

,The Qur'an as scripture, New York: R. F. Moore , Islam: Muhammad and His Religion, New York: The Liberal Art Press.Inc, 1958.

, The Foreign Vocabulary of the Qur'an, Volume III, Leiden: Brill, 2007.

Jeffery, Arthur, A Variant Text of the Fatiha, The Muslim World, Volume 29, 1939. 19, 1929.

Christian at Mecca, The Muslim World. Volume

, The Quest of The Historical Mohammed, The Muslim World, Volume 16, 1926.

Mujahid, Ibnu, Kitāb al-Sab'ah fỉ al-Qirā'at, Cetakan II, Kairo: Dar al-Ma'arif, $324 \mathrm{H}$.

Mustaqim, Abdul, Metode Penelitian Al-Qur'an dan Tafsir, Yogyakarta: Idea Press Yogyakarta, 2014.

Noldeke, Theodor, The History of the Qur'an, Leiden: Brill, 2013.

Qadhi, Abdul Fatah, Al-Budūr al-Zāhirah fī al-Qirā'at al-'Asr alMutawātirah, Beirut: Dar Kitab al-Ma’arif, 1403 H.

Qaththan, Manna, Mabāhis fi 'Ulūm al-Qur'an. Riyadh: Mansyurat al- 'Ashr al-Hadits, 1990.

Rauf, Hasan Abdul \& Abdurrahman Ghirah, Orientalisme dan Missionarisme: Menelikung Pola Pikir Umat Islam, Bandung: Remaja Rosdakarya, 2007.

Razi, Fakhruddin, Tafsìr al-Kabìr auw Mafătịh al-Gaib, Juz I, Beirut: Dar al-Fikr, 1981.

Reynolds, Gabriel Said (ed), The Qur'an in Its Historical Context, London: Routledge, 2008.

Saeed, Abdullah, The Qur'an: an Introduction, New York: Routledge, 2008.

Safitri, Arif Nur, Analisi Kritis Atas Ahistoritas Pemikiran Arthur Jeffery, Jurnal Al-Adalah, Vol 17, No 1, 2014.

Small, Keith E, Textual Criticism and Qur'an Manuscripts, UK: Rowman \& Littlefield Publisher,inc, 2011. 
Syahin, Abdul Syabur, Saat Al-Qur'an Butuh Pembelaan: Sebuah Analisis Sejarah, Jakarta: Penerbit Erlangga, 2006.

Zarkasyi, Hamid Fahdy, Tradisi Orientalis dan Framework Studi Al-Qur'an, Jurnal Tsaqafah, 2011. 